\title{
AKTIVITAS SENYAWA FENOL DALAM BUAH MENGKUDU (Morinda citrifolia) SEBAGAI ANTIBAKTERI ALAMI UNTUK PENGHAMBATAN BAKTERI PENYEBAB MASTITIS
}

\author{
ACTIVITY OF PHENOL OF Morinda citrifolia AS NATURAL ANTIBACTERIA TO INHIBIT THE \\ GROWTH OF MASTITIS-ASSOCIATED BACTERIA
}

\author{
Theresia Ika Purwantiningsih*, Yustina Yuni Suranindyah, dan Widodo \\ Fakultas Peternakan, Universitas Gadjah Mada, Jl. Fauna No. 3, Bulaksumur, Yogyakarta, 55281
}

\section{INTISARI}

Mastitis pada sapi perah merupakan salah satu penyakit yang menyebabkan penurunan kualitas dan produksi susu. Tujuan dari penelitian ini adalah untuk mengetahui dan mengukur kadar senyawa fenol dalam buah mengkudu (Morinda citrifolia) mentah, mengkal, dan matang, membandingkan daya hambat bakteri ekstrak buah mengkudu dan larutan celup puting komersial yang mengandung iodium 1,25\% (komersial A) dan benzalkonium chloride $2 \%$ (komersial B). Penelitian ini menggunakan bakteri Staphylococcus aureus asal susu sapi penderita mastitis subklinis. Larutan yang digunakan untuk menghambat bakteri adalah ekstrak buah mengkudu, larutan komersial A dan komersial B. Hasil penelitian menunjukkan kadar fenol paling tinggi terdapat pada buah mengkudu matang. Berdasarkan analisis statistik menggunakan One Way Anova menunjukkan bahwa pemberian larutan yang berbeda memberikan efek nyata $(\mathrm{P}<0,05)$ dalam uji daya hambat bakteri. Namun demikian hasil uji lanjut menggunakan uji Duncan's Multiple Range Test (DMRT) terdeteksi bahwa daya hambat bakteri yang diberi ekstrak buah mengkudu dan larutan komersial A tidak menunjukkan perbedaan. Sedangkan larutan komersial B mampu menghambat bakteri Staphylococcus aureus paling baik dibandingkan dengan ekstrak buah mengkudu, komersial A dan kontrol. Kesimpulannya, ekstrak mengkudu mengandung antibakteri alami dengan daya hambat yang tidak berbeda nyata dengan larutan komersial A dan dapat digunakan sebagai larutan untuk celup puting.

(Kata kunci: Fenol, Antibakteri alami, Morinda citrifolia)

\section{ABSTRACT}

Mastitis is one of the most harmful diseases on dairy cows because it reduced milk quality and production. The aim of this study was to determine the active compounds in the noni (Morinda citrifolia) fruit extract, to measure the levels of phenolic compounds in different stage of fruit maturity and to compare the activity of bacterial between noni fruit extract and commercial teat dipping solution containing $1.25 \%$ iodine (commercial A) and benzalkonium chloride 2\% (commercial B). This study employed Staphylococcus aureus bacteria originally isolated from subclinical mastitis cow. The highest levels of phenols were presented in ripe noni fruit. Based on statistical analysis using One Way Anova followed by Duncan's Multiple Range Test $(D M R T)$, there were significant differences $(P<0.05)$ in bacterial inhibition test between noni fruit extract, commercial A, commercial $B$, and control. The data showed that the inhibition of bacterial extracts of noni and commercial $A$ was not significantly different $(P>0.05)$. Commercial $B$ inhibited Staphylococcus aureus bacteria better than noni fruit extract, commercial A and control. As conclusion, fruit noni extract that of contains natural antibacterial with bacterial activity is not significant with commercial A.

(Keyword: Phenol, antibacteria, Morinda citrifolia)

\section{Pendahuluan}

Mastitis atau radang kelenjar ambing merupakan suatu penyakit yang dapat menyerang sapi perah, kambing perah atau kerbau perah (Setiadi, 1997), merupakan peradangan yang bersifat kompleks dengan berbagai variasi penyebab, derajat keparahan, lama penyakit, dan akibat penyakit yang beragam (Sudarwanto dan Sudarnika, 2008). Penyebab utama kerugian ekonomi dalam industri persusuan dan menurunkan produksi susu ialah mastitis (Azizoglu et al., 2013).

\footnotetext{
* Korespondensi (corresponding author):

Telp. +62 85293330549

E-mail: theresiapurwantiningsih@yahoo.co.id
}

Menurut Bruno (2010), bakteri patogen penyebab mastitis adalah Streptococcus agalactie, Mycoplasma bovis dan Staphylococcus aureus. Mastitis juga dapat disebabkan oleh bakteri yang berada di sekitar lingkungan, seperti Escherichia coli dan Klesbsilla sp. Menurut Goodwin et al. (1996) survei terhadap bakteri penyebab mastitis klinis di South-East Quennsland menunjukkan bahwa 38,5\% mastitis klinis disebabkan oleh Staphylococcus aureus, $12 \%$ disebabkan oleh Streptococcus agalactie, 6,6\% oleh Streptococcus dysgalactie, 3,4\% oleh Streptococcus uberis, 2,6\% oleh Coliform spp dan 0,6\% oleh Pseudomonas spp. 
Celup puting adalah salah satu cara yang efektif dalam mengurangi infeksi mastitis, khususnya yang disebabkan oleh bakteri. Pencelupan seluruh puting (dipping) setelah pemerahan memiliki dampak yang sangat besar dalam pengurangan jumlah sel somatik di dalam susu (Jones, 1998). Iodine dan chlorhexidine umumnya digunakan sebagai desinfektan untuk celup puting (Azizoglu et al., 2013). Menurut Subronto (2003), dipping setelah pemerahan dengan chlorine 4\% atau iodium, maupun alkohol $70 \%$ dapat digunakan dalam tindakan pencegahan penyebaran kuman. Pencelupan puting dengan 1\% iodine akan menambah kandungan iodine dalam susu sapi. Residu iodine meningkat dalam susu sebesar 80 menjadi $100 \mu \mathrm{g} / \mathrm{L}$ ketika 1\% iodophor digunakan dalam celup puting (Boddie dan Nickerson, 1989). Diketahui bahwa obat-obat antimikrobia dapat mengakibatkan alergi dan resisten bakteri. Di samping penggunaan iodine dan chlorhexadine sebagai bahan untuk celup puting, telah dikembangkan celup puting menggunakan bahan alam, yaitu buah mengkudu (Morinda citrifolia).

Mengkudu memiliki aktivitas antibakteri, antiviral, antifungi, antitumor, antihelmik, analgesik, hipotensif, antiinflamasi, dan efek peningkatan imun (Usha et al., 2010). Ekstrak buah mengkudu matang memiliki senyawa antibakteri terhadap Pseudomonas aeruginosa, M. pyrogenes, Salmonella typhosa, S. Montevideo, $S$. schottmuelleri, Shigella paradys, Eschericia coli, Staphylococcus aureus, Bacillus subtilis, Clostridium perfingens, dan Vibrio parahaemolyticus. Konsentrasi fenol 3000 ppm menunjukkan aktivitas bakteriostatik terhadap $S$. typosa dan Staphylococcus aureus (Damayanti dan Suparjana, 2007). Tujuan dari penelitian ini adalah untuk mengetahui kandungan senyawa aktif di dalam mengkudu yang dapat menghambat bakteri penyebab mastitis, sehingga mengkudu dapat dimanfaatkan sebagai bahan celup puting alami menggantikan larutan celup puting komersial yang mengandung iodium $1,25 \%$ (komersial A) dan benzalkonium chloride $2 \%$ (komersial B).

\section{Materi dan Metode}

Penelitian dilakukan selama lima bulan mulai bulan Desember 2012 sampai April 2013. Analisis kualitatif dan kuantitatif senyawa fenol dilaksanakan di Laboratorium Penelitian dan Pengujian Terpadu (LPPT), Universitas Gadjah Mada, ekstraksi buah mengkudu matang dilaksanakan di Fakultas Farmasi, Universitas Gadjah Mada, dan uji daya hambat Staphylococcus aureus dilaksanakan di Laboratorium Mikrobiologi,
Fakultas Kedokteran Hewan, Universitas Gadjah Mada.

\section{Materi}

Materi yang digunakan untuk membuat ekstrak buah mengkudu terdiri dari buah mengkudu mentah, mengkal, dan matang, mesin penggiling (grinder ukuran 60 mesh), timbangan analitik, etanol, kain kasa, waterbath, dan air. Pembuatan larutan ekstrak mengkudu yaitu menggunakan ekstrak mengkudu, Carboxymethyl Cellulose (CMC), akuades, magnetic stirrer, erlenmeyer, dan timbangan analitik. Materi untuk menguji kualitatif senyawa fenol adalah ekstrak mengkudu (mentah, mengkal dan matang), etil asetat, plate silica gel, dan pereaksi ferri chloride. Materi yang digunakan untuk menguji total fenol adalah asam galat, pereaksi folin-ciocalteu, aquabides, sodium karbonat, waterbath suhu $40^{\circ} \mathrm{C}$, kuvet dan sodium karbonat. Materi yang digunakan untuk menguji daya hambat bakteri terdiri dari cawan petri, media Brain Heart Infusion Agar (BHIA), biakan bakteri Staphylococcus aureus umur 18 sampai 24 jam diisolasi dari susu yang berasal dari sapi penderita mastitis subklinis, alat untuk membuat sumuran dan jangka sorong.

\section{Metode}

Ekstraksi buah mengkudu. Buah mengkudu mentah, mengkal, dan matang dicuci dengan air mengalir, ditiriskan kemudian dipotong tipis-tipis (kurang lebih $3 \mathrm{~mm}$ ) dan dioven dengan suhu $50^{\circ} \mathrm{C}$ selama 48 jam. Setelah kering, dihaluskan dengan mesin penggiling (grinder), hasil serbuknya ditimbang. Serbuk mengkudu yang dihasilkan dimaserasi dengan pelarut etanol $95 \%$ dengan perbandingan 1:7 (setiap 1 gram serbuk mengkudu, direndam dalam $7 \mathrm{ml}$ etanol) selama 24 jam, sambil diaduk-aduk. Hasil yang didapatkan disaring dengan kain kasa sehingga diperoleh hasil maserasi cair dan ampas. Hasil maserasi cair diuapkan di atas waterbath selama 3 hari atau sampai terbentuk gel dan etanol benar-benar menguap. Ekstrak buah mengkudu yang dihasilkan berupa gel.

Pembuatan larutan ekstrak buah mengkudu. Sebelum membuat larutan ekstrak mengkudu, pertama-tama membuat larutan $0,1 \%$ Carboxymethyl Cellulose (CMC). Sebanyak 0,1 g CMC dimasukkan ke dalam erlenmeyer dan ditambah aquades sampai volume $100 \mathrm{ml}$ kemudian dihomogenkan menggunakan magnetic stirrer. Ekstrak mengkudu matang ditimbang sebanyak 40 g, kemudian ditambahkan larutan CMC hingga volume $100 \mathrm{ml}$, dan diaduk sampai ekstrak tercampur seluruhnya.

Uji kualitatif senyawa fenol. Ekstrak mengkudu sebanyak $50 \mathrm{mg}$ ditimbang dan 
ditambahkan $1 \mathrm{ml}$ etil asetat. Campuran tersebut divortex selama 2 menit, kemudian disentrifuge selama 3 menit. Fase cair yang dihasilkan diambil dan diteteskan sebanyak $10 \mu \mathrm{l}$ pada plate silica gel. Plate dimasukkan ke dalam chamber jenuh fase gerak methanol:asam formiat perbandingan 94:6. Kemudian dioleskan hingga batas lalu plate dikeringkan dan diamati di bawah sinar UV. Hasil yang diperoleh disemprot dengan pereaksi ferri choride. Keberadaan senyawa fenol akan menghasilkan warna biru kelabu.

Uji total fenol. Pembuatan kurva baku standar. Larutan baku standar asam galat ditimbang sebanyak $10 \mathrm{mg}$ kemudian ditambahkan $0,5 \mathrm{ml}$ pereaksi folin-ciocalteu dan $7,5 \mathrm{ml}$ aquabides. Campuran tersebut dibiarkan selama 10 menit pada suhu kamar, kemudian ditambahkan 1,5 ml sodium karbonat $20 \%$. Campuran selanjutnya dipanaskan dalam waterbath pada suhu $40^{\circ} \mathrm{C}$ selama 20 menit dan didinginkan secepatnya pada cairan es. Hasil yang diperoleh diencerkan dengan aquabides hingga volume $10 \mathrm{ml}$. Kemudian dipindahkan ke dalam kuvet, serapan dibaca pada spektrofotometer pada panjang gelombang $760 \mathrm{~nm}$.

Penetapan uji total fenol. Pengujian uji total fenol menurut metode Chun et al. (2003). Ekstrak mengkudu diambil dan ditambahkan pereaksi folinciocalteu sebanyak $0,5 \mathrm{ml}$ dan 7,5 aquabides. Campuran tersebut dibiarkan selama 10 menit pada suhu kamar, kemudian ditambahkan 1,5 ml sodium karbonat 20\%. Campuran dipanaskan dalam waterbath pada suhu $40^{\circ} \mathrm{C}$ selama 20 menit dan secepatnya didinginkan pada cairan es, lalu diencerkan dengan aquabides hingga volume $10 \mathrm{ml}$, dipindahkan ke dalam kuvet, serapan dibaca pada spektrofotometer pada panjang gelombang $760 \mathrm{~nm}$. Perhitungan total fenol setara asam galat pada buah mengkudu mentah, mengkal, dan matang disajikan pada Tabel 1.

Uji daya hambat bakteri. Pelaksanaan uji daya hambat bakteri dilakukan secara antiseptik dengan metode sumuran menurut Cavalieri (2005).
Bakteri yang digunakan adalah Staphylococcus aureus yang berumur kurang dari 18 sampai 24 jam. Bakteri diinokulasikan ke cawan petri yang telah diberi media BHIA. Setelah itu dibuat lubang dengan diameter $\pm 6 \mathrm{~mm}$. Ke dalam lubang tersebut diberi larutan kontrol (aquades), ekstrak buah mengkudu dan larutan celup puting komersial A dan B sebanyak $50 \mu \mathrm{L}$. Cawan petri diinkubasi pada suhu $35^{\circ} \mathrm{C}$ selama 20 sampai 24 jam. Daerah bening di sekitar lubang menunjukkan uji positif, kemudian diameter daerah bening di setiap lubang diukur menggunakan jangka sorong.

\section{Analisis data}

Data yang diperoleh dianalisis menggunakan One Way Anova dan apabila hasilnya signifikan dilanjutkan dengan uji Duncan's Multiple Range Test (DMRT).

\section{Hasil dan Pembahasan}

\section{Kandungan fenol dalam mengkudu}

Penelitian ini menggunakan buah mengkudu pada tingkat kematangan yang berbeda. Buah mengkudu mentah berwarna hijau tua, keras, dan tidak berbau. Buah mengkudu mengkal berwarna hijau muda, sedikit lunak, dan tidak berbau, sedangkan buah mengkudu matang berwarna putih kehijauan, lembek, dan berbau khas. Gambar 1, 2 dan 3 adalah buah mengkudu mentah, mengkal, dan matang.

Hasil test terhadap senyawa fenol dan flavonoid dalam buah mengkudu disajikan pada Tabel 2. Hasil positif pada Tabel 2 menunjukkan bahwa ekstrak buah mengkudu mentah, mengkal dan matang mempunyai kandungan senyawa flavonoid dan fenol. Adanya senyawa flavonoid ditunjukkan dengan munculnya warna kuning dan adanya senyawa fenol ditunjukkan dengan munculnya warna biru kelabu pada Gambar 4a dan $4 b$.

Tabel 1. Perhitungan total fenol setara asam galat (total phenol equivalent galic acid)

\begin{tabular}{lccccc}
\hline \hline Sampel (sample) & $\begin{array}{l}\text { Berat sampel } \\
(\mathrm{mg})(\text { sample } \\
\text { weight }(\mathrm{mg}))\end{array}$ & $\mathrm{FP}(\mathrm{x})$ & $\begin{array}{c}\text { Konsentrasi } \\
\text { sampel }(\mathrm{ppm}) \\
\text { (sample } \\
\text { concentration } \\
(\text { ppm) }\end{array}$ & $\begin{array}{c}\text { Fenol dalam } \\
\text { sampel (ppm) } \\
(\text { phenol in } \\
\text { sample }(\text { ppm) })\end{array}$ & $\begin{array}{c}\text { Total fenol setara } \\
\text { asam galat (\%) (total } \\
\text { phenol equivalent } \\
\text { galic acid (\%) })\end{array}$ \\
\hline $\begin{array}{l}\text { Buah mentah } \\
\text { (raw noni) }\end{array}$ & 0,0504 & 5 & 1008 & 22,560 & 2,24 \\
$\begin{array}{l}\text { Buah mengkal } \\
\text { (unripe noni) }\end{array}$ & 0,0505 & 5 & 1010 & 36,854 & 3,65 \\
$\begin{array}{l}\text { Buah matang } \\
\text { (ripe noni) }\end{array}$ & 0,0506 & 5 & 1012 & 62,506 & 6,18 \\
\hline
\end{tabular}




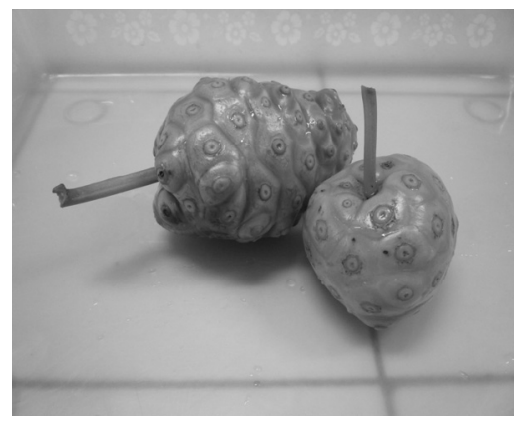

Gambar 1. Buah mengkudu mentah (raw noni).

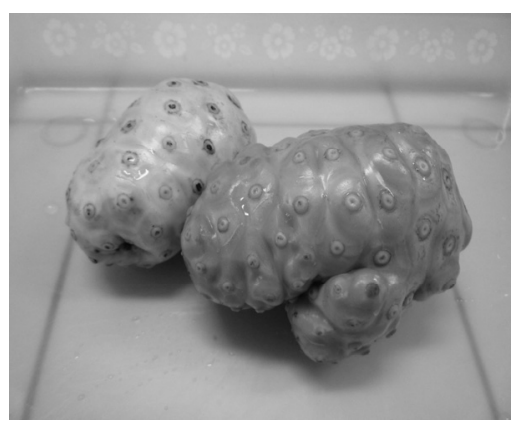

Gambar 2. Buah mengkudu mengkal (unripe noni).

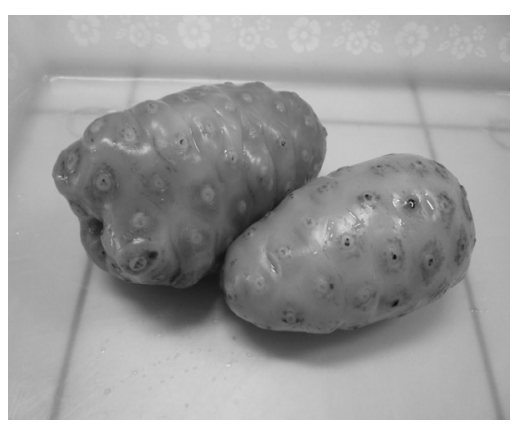

Gambar 3. Buah mengkudu matang (ripe noni).

Tabel 2. Hasil analisis kualitatif buah mengkudu (qualitative analysis of noni fruit)

\begin{tabular}{lcc}
\hline \hline \multicolumn{1}{c}{ Sampel (sample) } & $\begin{array}{c}\text { Hasil kualitatif flavonoid } \\
\text { (qualitative result of } \\
\text { flavonoid) }\end{array}$ & $\begin{array}{c}\text { Hasil kualitatif senyawa } \\
\text { fenol (qualitative result of } \\
\text { phenol) }\end{array}$ \\
\hline Buah mengkudu mentah (raw noni) & Positif & Positif \\
Buah mengkudu mengkal (unripe noni) & Positif & Positif \\
Buah mengkudu matang (ripe noni) & Positif & Positif \\
\hline
\end{tabular}

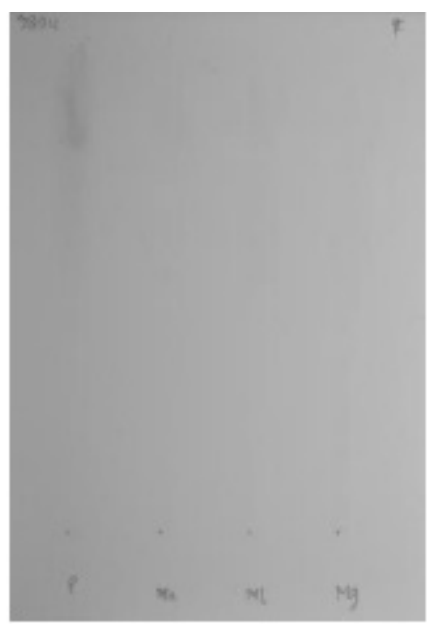

Gambar 4a. Warna kuning pada visible menunjukkan adanya flavonoid (the yellow indicates the presence of flavonoids in the visible).

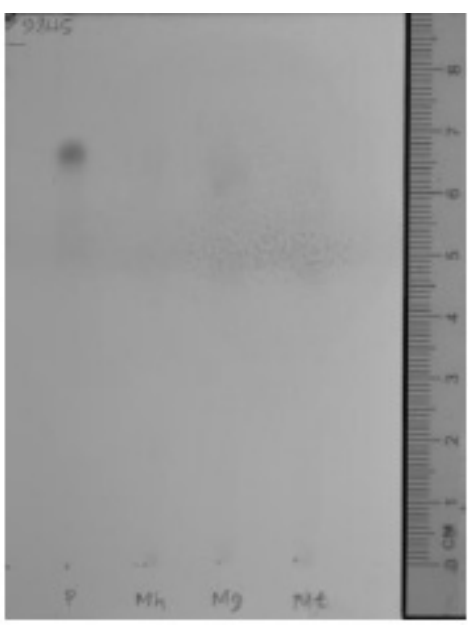

Gambar 4b. Warna biru kelabu pada visible menunjukkan adanya fenol (the blue indicates the presence of visible gray on phenol).

Tabel 3. Hasil analisis kuantitatif buah mengkudu (quantitative analysis of noni fruit)

\begin{tabular}{lc}
\hline \multicolumn{1}{c}{ Sampel (sample) } & Total fenol ekuivalen asam galat (\%) \\
& (total phenol equivalent galic acid (\%)) \\
\hline Buah mengkudu mentah (raw noni) & 2,24 \\
Buah mengkudu mengkal (unripe noni) & 3,65 \\
Buah mengkudu matang (ripe noni) & 6,18 \\
\hline
\end{tabular}

Hasil penelitian sebagaimana disajikan pada Tabel 3, menunjukkan bahwa buah mengkudu mempunyai antibakteri alami yaitu fenol dan flavonoid dan buah mengkudu matang memiliki kadar fenol paling tinggi. Menurut Yang et al. (2011), kematangan meningkatkan kandungan antioksidan, total fenol dan kandungan asam askorbat dari buah mengkudu, sehingga semakin 62 matang, kandungan total fenol pada buah mengkudu semakin besar.

Fenol telah dipelajari secara ekstensif sebagai desinfektan yang mempunyai aktivitas antibakteri berspektrum luas terhadap bakteri Gram positif dan Gram negatif (Oliver et al., 2001). Menurut Rohman et al. (2006), senyawa fenol yang terdapat pada buah mengkudu berkisar antara 5,94 sampai 
$36,52 \mathrm{~g}$ setara asam galat/100 g bahan kering. Kadar senyawa fenol dalam buah mengkudu dalam penelitian ini dibandingkan penelitian sebelumnya sedikit berbeda. Menurut Deng et al. (2010), variasi kandungan buah mengkudu satu tempat ke tempat lain disebabkan karena faktor lingkungan geografis, seperti tanah, sinar matahari, temperatur dan kelembaban udara.

\section{Uji daya hambat terhadap Staphylococcus aureus}

Staphylococcus aureus merupakan bakteri yang paling dominan pada penyakit mastitis, dominansinya mencapai 55 sampai $70 \%$ dari populasi bakteri mastitis (Sufiriyanto dan Indraji, 2005). Tabel 4 dan Gambar 5 menunjukkan lebar zona bening yang dibentuk. Berdasarkan lebar zona bening yang dibentuk pada Tabel 4, larutan komersial $\mathrm{B}$ yang mengandung chlorhexidine mempunyai zona penghambatan yang paling luas daripada ekstrak buah mengkudu, larutan komersial A dan kontrol.

Komersial B mempunyai daya hambat yang lebih besar dari ekstrak buah mengkudu dan komersial A (Tabel 4). Pembentukan daerah zona bening yang lebih besar menunjukkan bahwa komersial B lebih baik dalam menghambat pertumbuhan bakteri Staphylococcus aureus. Komersial A dan ekstrak mengkudu memiliki daya hambat yang hampir sama. Tingginya daya hambat bakteri pada larutan komersial B karena larutan komersial $\mathrm{B}$ adalah larutan antibakteri yang berspektrum luas, sedangkan larutan komersial A dan ekstrak mengkudu hanya mampu membunuh bakteri yang spesifik.

Penelitian ini menggunakan bakteri Staphylococcus aureus karena dominansinya mencapai 55 sampai $70 \%$ dari populasi bakteri mastitis. Sufiriyanto dan Indraji (2005) menyatakan bahwa bakteri Gram positif yang sering dihubungkan dengan mastitis klinis dan subklinis. Bakteri Gram positif tidak tahan terhadap senyawa fenol dan antraquinon. Senyawa fenol dan antraquinon dari buah mengkudu menekan pertumbuhan bakteri Gram positif karena kemampuan penetrasi senyawa ini dalam dinding sel bakteri. Senyawa fenol dan antraquinon termasuk senyawa yang larut lemak.

Golongan fenol mampu merusak membran sel, menginaktifkan enzim dan mendenaturasi protein sehingga dinding sel mengalami kerusakan karena penurunan permeabilitas. Perubahan permeabilitas membran sitoplasma memungkinkan terganggunya transportasi ion-ion organik yang penting ke dalam sel sehingga berakibat terhambatnya pertumbuhan bahkan hingga kematian sel (Damayanti dan Suparjana, 2007). Dalam konsentrasi tinggi, kandungan fenol menembus dan mengganggu dinding sel bakteri dan mempresipitasi protein dalam sel bakteri. Dalam konsentrasi yang lebih rendah, fenol menginaktifkan sistem enzim penting dalam sel bakteri (Oliver et al., 2001).

Berdasarkan penelitian yang dilakukan Puspitasari et al. (2012), konsentrasi perasan buah mengkudu $40 \%$ mempunyai warna yang sangat

Tabel 4. Uji daya hambat terhadap Staphylococcus aureus (inhibition of bacterial test Staphylococcus aureus)

\begin{tabular}{ccccc}
\hline \hline & $\begin{array}{c}\text { Kontrol }(\mathrm{mm}) \\
(\text { control }(\mathrm{mm}))\end{array}$ & $\begin{array}{c}\text { Ekstrak buah mengkudu }(\mathrm{mm}) \\
\text { fruit noni extract }(\mathrm{mm}))\end{array}$ & $\begin{array}{c}\text { Komersial A }(\mathrm{mm}) \\
(\text { commercial } \mathrm{A}(\mathrm{mm}))\end{array}$ & $\begin{array}{c}\text { Komersial B }(\mathrm{mm}) \\
(\text { commercial B }(\mathrm{mm}))\end{array}$ \\
\hline I & 0,00 & 11,00 & 10,33 & 16,00 \\
II & 0,00 & 12,00 & 11,67 & 20,33 \\
III & 0,00 & 12,16 & 10,00 & 17,00 \\
\hline
\end{tabular}

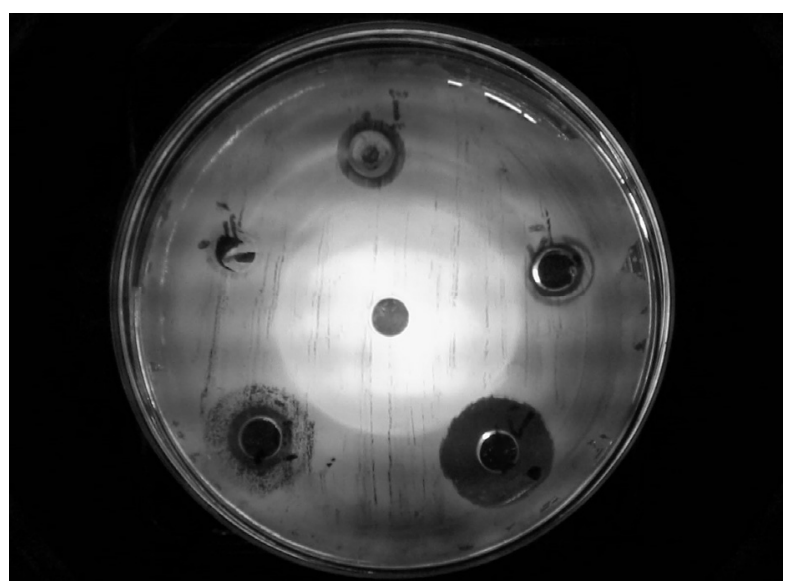

Gambar 5. Uji in vitro terhadap Staphylococcus aureus (in vitro test in Staphylococcus aureus). 
jernih yang menunjukkan bahwa pertumbuhan bakteri Staphylococcus aureus telah dapat dihambat. Perasan buah mengkudu matang mempunyai daya antibakteri bakteriostatik dan bakterisidal terhadap bakteri Staphylococcus aureus secara in vitro dan semakin tinggi konsentrasi perasan buah mengkudu matang yang diberikan maka pertumbuhan bakteri Staphylococcus aureus akan semakin rendah.

\section{Kesimpulan}

Buah mengkudu mengandung senyawa fenol dan flavonoid yang dapat berfungsi sebagai antibakteri alami dengan kandungan fenol paling tinggi diperoleh dari buah mengkudu matang. Uji daya hambat bakteri menunjukkan bahwa larutan komersial B mempunyai zona penghambat Staphylococcus aureus lebih baik, dibandingkan daya hambat ekstrak buah mengkudu dan larutan komersial A. Ekstrak buah mengkudu dapat digunakan sebagai larutan untuk celup puting yang aman karena mengandung antibakteri alami dengan daya hambat yang tidak berbeda nyata dengan larutan komersial A.

\section{Daftar Pustaka}

Azizoglu, R. O., R. Lyman and K. L. Anderson. 2013. Bovine Staphylococcus aureus: Dose response to iodine and chlorhexidine and effect of iodine challenge on antibiotic susceptibility. J. Dairy Sci. 96: 993-999.

Boddie, R. L. and S. C. Nickerson. 1989. Efficacy of $0.18 \%$ iodine teat dip against Staphylococcus aureus and Staphylococcus agalactiae. J. Dairy Sci. 72: 1063-1066.

Bruno, D. R. 2010. Mastitis, mammary gland immunity, and nutrition. Mid-South Ruminant Nutrition Conference. Arlington. Texas.

Cavalieri, S. J. 2005. Manual of Antimicrobial Susceptibility Testing. American Society for Microbiology. Pan American Health Organization.

Chun, O. K., D. O. Kim and C. Y. Lee. 2003. Superoxide radical scavenging activity of the major polyphenols in fresh plums. J. Agric. Food Chem. 51: 8067-8072.

Damayanti, E. dan T. B. Suparjana. 2007. Efek penghambatan beberapa fraksi ekstrak buah mengkudu terhadap Shigella dysenteriae. Prosiding Seminar Nasional Tehnik Kimia Kejuangan. Fakultas Biologi Universitas Jenderal Soedirman. Yogyakarta: 30 Januari 2007.
Deng, S., B. J. West and C. J. Jensen. 2010. A quantitative comparison of phytochemical components in global noni fruits and their commercial product. Food Chem. 122: 267270.

Goodwin, P. J., G. R. Kenny, M. J. Josey and M. Imbeah. 1996. Effectiveness of postmilking teat antisepsis with iodophor, chlorhexidine or dodecyl benzene sulphonic acid. Proc. Aust. Soc. Prod. 21: 266-269.

Jones, G. M. 1998. Milking practices recommended to assure milk quality and prevent mastitis. J. Dairy Sci. 89: 3696-3701.

Oliver, S. P., B. E. Gillespie, M. J. Lewis, S. J. Ivey, R. A. Almeida, D. A. Luther, D. L. Johnson, K. C. Lamar, H. D. Moorehead and H. H. Dowlen. 2001. Efficacy of a new premilking teat disinfectant containing a phenolic combination for the prevention of mastitis. J. Dairy Sci. 84: 1545-1549.

Puspitasari, G., S. Muwarni, dan Herawati. 2012. Uji daya antibakteri perasan buah mengkudu (Morinda citrifolia) terhadap bakteri Methicillin resistant Staphylococcus aureus (MRSA) M.2036 in vitro. Skripsi. Program Studi Pendidikan Dokter Hewan. Program Kedokteran Hewan. Universitas Brawijaya.

Rohman, A., S. Riyanto, dan D. Utari. 2006. Aktivitas antioksidan, kandungan fenol total dan kandungan flavonoid total ekstrak etil asetat buah mengkudu serta fraksi-fraksinya. Majalah Farmasi Indonesia 17: 136-142.

Setiadi, Y. 1997. Deteksi mastitis subklinis pada sapi perah dengan Aullendorfer Mastitis Probe (AMP) test. Lokakarya Fungsional Non Peneliti.

Subronto. 2003. Ilmu Penyakit Ternak. Gadjah Mada University Press. Yogyakarta.

Sudarwanto, M. dan E. Sudarnika. 2008. Hubungan antara $\mathrm{pH}$ susu dengan jumlah sel somatic sebagai parameter mastitis subklinik. Media Peternakan 31: 107-113.

Sufiriyanto dan M. Indraji. 2005. Uji in vitro dan in vivo ekstrak campuran mengkudu (Morinda citrifolia) dan bawang putih (Allium sativum) pada sapi perah penderita mastitis sub klinis. J. Anim. Prod. 7: 101-105.

Usha, R., S. Sangeetha and P. Palaniswamy. 2010. Antimicrobial activity of rarely known species, Morinda citrifolia, L. Ethnobotanical Leaflet 14: 306-311.

Yang, J., R. Gadi and T. Thomson. 2011. Antioxidant capacity, total phenol and ascorbic acid content of noni (Morinda citrifolia) fruits and leaves at various stages of maturnity. Micronesica 41: 167-176. 